\title{
Prevalence, Virulence Genes and Antimicrobial Profiles of Escherichia Coli 0157:H7 Isolated from Healthy Cattle
}

Ghassan Tayh ( $\sim$ ghassan.tayh@gmail.com )

Universite de la Manouba https://orcid.org/0000-0002-7180-6787

\section{Salma Mariem Boubaker}

Universite de la Manouba

Rym Ben Khedher

Universite de la Manouba

Mounir Jbeli

Universite de la Manouba

Faten Ben Chehida

Universite de la Manouba

Aymen Mamlouk

Universite de la Manouba

Monia Dâaloul-Jedidi

Universite de la Manouba

Lilia Messadi

Universite de la Manouba

\section{Research Article}

Keywords: Escherichia coli 0157:H7, Healthy cattle, Antimicrobial susceptibility, Virulence factors, Shiga toxins, Tunisia.

Posted Date: June 8th, 2021

DOI: https://doi.org/10.21203/rs.3.rs-580804/v1

License: @ (i) This work is licensed under a Creative Commons Attribution 4.0 International License. Read Full License 


\section{Abstract}

Background: Shiga toxin-producing Escherichia coli (STEC) 0157:H7 is associated with intestinal infection in human and considered a main cause of food-borne diseases. It was isolated from animals, human and food. The aim of the study was to assess the incidence of $E$. coli 0157:H7 in fecal samples of healthy cattle collected in slaughterhouses $(n=160)$ and from farms $(n=100)$.

Methods: E. coli isolates were detected on MacConkey agar. A total of $236 \mathrm{E}$. coli isolates were recovered from fecal samples of healthy cattle. We used sorbitol MacConkey to detect non-sorbitol fermenting colonies that were examined for the presence of 0157 antigen by latex agglutination, and positive bacteria were screened for the existence of $s t \times 1$, stx2, eaeA and $e h \times A$ by PCR as well as IfbEO157 and fliCH7 genes specific for serotype 0157 . All isolates were examined for the susceptibility against 21 antibiotics discs.

Results: Of the 236 E. coli isolates, 4.2\% (10/236) were positive for STEC 0157:H7. Shiga toxin gene (stx2) was present in $70 \%$ of isolates, st 1 and $e h x A$ were confirmed in $60 \%$ of the isolates, whereas eae was identified in two isolates. Other virulence factors screened ( $f i m H, s f a / f o c D E, c d t 3$, traT, iutA and $h l y$ ) were present among the 10 isolates. All E. coli 0157:H7 isolates were sensitive to amoxicillin/clavulanic acid, cefotaxime, cefepime, aztreonam, colistin and sulfamethoxazole/trimethoprim. All isolates belong to the phylo-group E.

Conclusion: This is the first study of the incidence of E. coli 0157:H7 in cattle in Tunisia. Our finding proves the existence of STEC 0157:H7 in healthy animals producing food for human consumption which could be a source of human contamination.

\section{Introduction}

Escherichia coli is a common bacteria of the intestinal microbiota and an important pathogen in animals, human and public health (Tayh et al. 2016). The pathogenic E. coli strains are classified into extraintestinal pathogenic strains (causing urinary tract infection, meningitis, diverse intraabdominal infections and pneumonia) and intestinal pathogenic (diarrheagenic) strains that causing gastroenteritis (Johnson, Russo 2002). According to virulence determinants, diarrheagenic E. coli (DEC) are categorized as enterotoxigenic (ETEC), enterohemorrhagic (EHEC), enteroinvasive (EIEC), enteroaggregative (EAggEC), diffusely adherent (DAEC), and enteropathogenic $E$. coli (EPEC) (Hashish et al. 2016).

Strains belonging to the subgroup of shiga toxin-producing strains (STEC) are distinguished by certain EHEC serotypes, which are considerably linked to outbreaks in humans and causes clinical sickness. STEC is a foodborne bacteria which have been associated to many epidemics in all continents especially serotype 0157:H7 (Karmali 1989). STEC strains were isolated from faeces of healthy ruminants like cattle, goats and sheep which can be natural reservoirs of these pathogens (Persad, Lejeune 2015).

E. coli 0157:H7 is the dominant serotype of STEC group associated with human infections. The first identification of this serotype as a pathogen was in 1982 during an outbreak of hemorrhagic colitis in Oregon and Michigan, U.S.A (Riley et al. 1983). The STEC 0157:H7 can cause acute infections, with a spectrum of human illnesses ranging from abdominal pain, bloody diarrhea to fatal disease, like hemolytic-uremic syndrome 
(HUS) and hemorrhagic colitis (HC). The main STEC 0157 infections are food borne more particularly concerning cattle sources (Atnafie et al. 2017).

The STEC strains possess shiga toxins (stx1 and stx2) genes which consider the major virulence factors of these strains. Stx2 is associated more closely with the sickness than stx1 (García-Aljaro et al. 2004). Other important virulence determinants are: intimin protein, encoded by eae gene and important for attaching and effacing activity within the colonization of host intestinal mucosa and cause severe human infections, and enterohemolysin is encoded by the plasmid- and phage-carried enterohemolysin $(e h x A)$ gene (Al-Gallas et al. 2006).

STEC 0157:H7 isolates have been detected in north Africa from humans, animals and food products. An Algerian study identified a rate of $7 \%$ from bovine carcasses (Chahed et al. 2006). In Morocco, a prevalence of STEC 0157:H7 was $9 \%, 9.1 \%$ and $11.1 \%$ from raw meat products, dairy products and marketed meat respectively (Beneduce et al. 2008,Benkerroum et al. 2004). A Tunisian study comfirmed that $3.4 \%$ of E. coli isolates among human stool samples were STECand 0.3\% was E. coli 0157:H7 (Al-Gallas et al. 2006). In Egypt, a survey confirmed that the prevalence among beef samples, chicken samples and lamb samples was $6 \%, 4 \%$ and $4 \%$ respectively (Abdul-Raouf et al. 1996).

An increasing rate of STEC 0157 outbreaks, is related to the human consumption of fruits and vegetables contaminated with domestic or wild animal faeces. E. coli 0157:H7 is transmitted to human by consumption of contaminated foods like raw meat, undercooked meat and raw milk. Contaminated water and foods by faecal material and cross-contamination through food production and processing, will lead to STEC infection (Lupindu 2018). Therefore, the objective of our study was to assess the incidence, virulence genes and antimicrobial resistance profiles of E. coli 0157:H7 in fecal samples of healthy cattle. To the best of our knowledge, this is the first detection report of $E$. coli 0157 in healthy cattle in the Tunisia.

\section{Materials And Methods}

\section{Samples Collection}

The sample collection in this study was conducted on two types; firstly, faecal samples from 160 cattle intended for slaughter collected between December 2016 and April 2017. These samples were collected from five slaughterhouses in the greater Tunis, namely: El Ouardia slaughterhouse, Mornag slaughterhouse, Fouchana slaughterhouse, Khelidia slaughterhouse and Ezzahra slaughterhouse. In the second sampling method, a total of 100 faecal samples were gathered from healthy cattle between March and November 2018 from cattle farms located in the governorate of Bizerte.

\section{Selective isolation ofE. coli0157:H7}

Fecal samples were enriched in buffered peptone water overnight at $37^{\circ} \mathrm{C}$, then cultured on MacConkey agar for 18 to 24 hours at $37^{\circ} \mathrm{C}$. The identification of E. coli colonies was performed by classical biochemical methods. The bacterial colonies were cultivated onto sorbitol MacConkey agar (Oxoid) supplemented with cefixime tellurite (CT-SMAC) and incubated for $18-24 \mathrm{~h}$ at $37^{\circ} \mathrm{C}$. All sorbitol nonfermenters (straw color or colorless) colonies each were picked as probablly E. coli 0157. 


\section{Agglutination Test Of 0157}

Each non-sorbitol-fermenting colony isolated on SMAC plates was examined for the existence of the 0157 antigens by agglutination latex reagent (Oxoid).

\section{Affirmation ofE. coli 0157by PCR}

All non-sorbitol fermenting $E$. coli isolates and 0157 agglutination-positive were examined for the existence of rfbE0157gene and fliCH7 by simplex PCR (Gannon et al. 1997). The PCR condition was as follows: initial denaturation at $94^{\circ} \mathrm{C}$ for $5 \mathrm{~min}$; 35 cycles of denaturation at $94^{\circ} \mathrm{C}$ for $45 \mathrm{sec}$, annealing at specific temperature for $45 \mathrm{sec}$ (Table 1), extension at $72^{\circ} \mathrm{C}$ for $45 \mathrm{sec}$; and a final extension $\left(72^{\circ} \mathrm{C}, 7 \mathrm{~min}\right)$.

A multiplex PCR for stx1, stx2, uidA, ehxA and eae was achieved for the 0157:H7 strains and primers arelisted in Table 1 (Al-Ajmi et al. 2020). The thermal cycling program of multiplex PCR was as follows, the denaturation: $95^{\circ} \mathrm{C}$ for $5 \mathrm{~min}$ followed by 25 cycles of $95^{\circ} \mathrm{C}$ for $1 \mathrm{~min}$, annealing at $56^{\circ} \mathrm{C}$ for $1 \mathrm{~min}$ and the extension at $72^{\circ} \mathrm{C}$ for $1 \mathrm{~min}$ and the final extension at $72^{\circ} \mathrm{C}$ for $5 \mathrm{~min}$. The gel electrophoresis was used to separated PCR products by using $2 \%$ agarose gel containing ethidium bromide.

The stx 1 and stx 2 amplifications were sequenced in order to prove that the amplicon matched to the stx 1 and stx2 sequences. The gained sequences were aligned with the data sequences in NCBI (http://www.ncbi.nlm.nih.gov).

\section{Virulence Genes}

PCR assay was used to study the presence of 13 virulence genes; cdt3 (cytolethal distending toxin), cnf1 (cytotoxic necrotizing factor), hly (hemolysin), aer (aerobactin system), papA (P fimbriae), bfpA (bundle forming pilus), papG allele III, fimH (type 1 fimbriae), traT (serum survival gene), ibeA (invasion of brain endothelium), sfa/foc (S and F1C fimbriae), iutA (aerobactin system) and fyuA (yersiniabactin).

\section{Antimicrobial Susceptibility Testing}

The antimicrobial susceptibility was determined by the disk-diffusion method on Mueller-Hinton agar plates as recommended by the Antibiogram Committee of the French Society (CA-SFM; www.sfm-microbiologie.org) using antibiotic disc panels comprising $\mu \mathrm{g}$ /disk: twelve $\beta$-lactam (amoxicillin (25), amoxicillin/clavulanic acid (20/10), ticarcillin/clavulanic acid (75/10), cefotaxime (30), ceftazidime (30), cefepime (30), cefoxitin (30), aztreonam (30) ertapenem (10), and piperacilline (30), cefalotine (30), cefuroxime (30)), and nine non- $\beta$-lactam (chloramphenicol (30), gentamicin (15), colistin (50), nalidixic acid (30), enrofloxacin (5), tetracycline (30) and sulfamethoxazole/trimethoprim (1.25/23.75), streptomycine and florfenicol).

\section{Detection Of Phylogenetic Groups}

The phylogenetic groups (A, B1, B2, C, D, E, F) were detected among the isolates by the quadruplex PCR method developed by Clermont et al. (Clermont et al. 2013). The phylo-groups determination established on the existence 
of the chuA, yjaA genes and TspE4-C2 fragment by the quadruplex PCR to detect (A, B1, B2, D) and C, E were further identified by using specific primer sets (Table 1). 
Table 1

Primers for PCR amplification of E. coli 0157:H7

\begin{tabular}{|c|c|c|c|c|c|}
\hline PCR reaction & Gene & Primer sequence $\left(5^{\prime}-3^{\prime}\right)$ & $\begin{array}{l}\text { Size of } \\
\text { PCR } \\
\text { product } \\
\text { (bp) }\end{array}$ & $\begin{array}{l}\text { Annealing } \\
\text { temperature } \\
\left({ }^{\circ} \mathrm{C}\right)\end{array}$ & Reference \\
\hline \multicolumn{6}{|c|}{ Phylogenetic genes } \\
\hline \multirow[t]{4}{*}{ Quadruplex } & chuA & $\begin{array}{l}\text { chuA.1b: } \\
\text { ATGGTACCGGACGAACCAAC } \\
\text { chuA.2: } \\
\text { TGCCGCCAGTACCAAAGACA }\end{array}$ & 288 & 60 & $\begin{array}{l}\text { (Clermont } \\
\text { et al. } \\
2013)\end{array}$ \\
\hline & yjaA & $\begin{array}{l}\text { yjaA.1b: } \\
\text { CAAACGTGAAGTGTCAGGAG } \\
\text { yjaA.2b: } \\
\text { AATGCGTTCCTCAACCTGTG }\end{array}$ & 211 & 60 & $\begin{array}{l}\text { (Clermont } \\
\text { et al. } \\
2013)\end{array}$ \\
\hline & TspE4C2 & $\begin{array}{l}\text { TspE4C2.1b: } \\
\text { CACTATTCGTAAGGTCATCC } \\
\text { TspE4C2.2b: } \\
\text { AGTTTATCGCTGCGGGTCGC }\end{array}$ & 152 & 60 & $\begin{array}{l}\text { (Clermont } \\
\text { et al. } \\
2013)\end{array}$ \\
\hline & $\operatorname{arp} A$ & $\begin{array}{l}\text { AceK.f: } \\
\text { AACGCTATTCGCCAGCTTGC } \\
\text { AceK.r: } \\
\text { TCTCCCCATACCGTACGCTA }\end{array}$ & 400 & 60 & $\begin{array}{l}\text { (Clermont } \\
\text { et al. } \\
\text { 2013) }\end{array}$ \\
\hline Group E & $\operatorname{arp} A$ & $\begin{array}{l}\text { ArpAgpE.f: } \\
\text { GATTCCATCTTGTCAAAATATGCC } \\
\text { ArpAgpE.r: } \\
\text { GAAAAGAAAAAGAATTCCCAAGAG }\end{array}$ & 301 & 57 & $\begin{array}{l}\text { (Clermont } \\
\text { et al. } \\
2013)\end{array}$ \\
\hline Group C & $\operatorname{trp} A$ & $\begin{array}{l}\text { trpAgpC.1: } \\
\text { AGTTTTATGCCCAGTGCGAG } \\
\text { trpAgpC.2: } \\
\text { TCTGCGCCGGTCACGCCC }\end{array}$ & 219 & 59 & $\begin{array}{l}\text { (Clermont } \\
\text { et al. } \\
2013)\end{array}$ \\
\hline Internal control & $\operatorname{trp} A$ & $\begin{array}{l}\text { trpBA.f: } \\
\text { CGGCGATAAAGACATCTTCAC } \\
\text { trpBA.r: } \\
\text { GCAACGCGGCCTGGCGGAAG }\end{array}$ & 489 & 57 & $\begin{array}{l}\text { (Clermont } \\
\text { et al. } \\
2013)\end{array}$ \\
\hline \multicolumn{6}{|l|}{ Virulence factors } \\
\hline Shiga toxin & stx1 & $\begin{array}{l}\text { F: CAGTTAATGTGGTGGCGAAGG } \\
\text { R: CACCAGACAATGTAACCGCTG }\end{array}$ & 348 bp & 56 & $\begin{array}{l}\text { (Sjöling et } \\
\text { al. 2015) }\end{array}$ \\
\hline Shiga toxin & stx2 & $\begin{array}{l}\text { F: ATCCTATTCCCGGGAGTTTACG } \\
\text { R: GCGTCATCGTATACACAGGAGC }\end{array}$ & 584 bp & 56 & $\begin{array}{l}\text { (Sjöling et } \\
\text { al. 2015) }\end{array}$ \\
\hline
\end{tabular}




\begin{tabular}{|c|c|c|c|c|c|}
\hline PCR reaction & Gene & Primer sequence $\left(5^{\prime}-3^{\prime}\right)$ & $\begin{array}{l}\text { Size of } \\
\text { PCR } \\
\text { product } \\
\text { (bp) }\end{array}$ & $\begin{array}{l}\text { Annealing } \\
\text { temperature } \\
\left({ }^{\circ} \mathrm{C}\right)\end{array}$ & Reference \\
\hline \multirow[t]{2}{*}{ Enterohaemolysin } & \multirow[t]{2}{*}{$e h x A$} & F: GCATCATCAAGCGTACGTTCC & \multirow[t]{2}{*}{534 bp } & \multirow[t]{2}{*}{56} & \multirow{2}{*}{$\begin{array}{l}\text { (Grispoldi } \\
\text { et al. } \\
2017 \text { ) }\end{array}$} \\
\hline & & R: AATGAGCCAAGCTGGTTAAGCT & & & \\
\hline \multirow{2}{*}{$\begin{array}{l}\text { Enteropathogenic } \\
\text { attachment and } \\
\text { effacement }\end{array}$} & \multirow[t]{2}{*}{ eae } & $\mathrm{F}:$ TGCGGCACAACAGGCGGCGA & \multirow[t]{2}{*}{$629 \mathrm{pb}$} & \multirow[t]{2}{*}{56} & \multirow{2}{*}{$\begin{array}{l}\text { (Ranjbar et } \\
\text { al. 2017) }\end{array}$} \\
\hline & & R: CGGTCGCCGCACCAGGATTC & & & \\
\hline \multicolumn{6}{|l|}{ Others } \\
\hline \multirow{2}{*}{$\begin{array}{l}\text { Part of O-antigen } \\
157\end{array}$} & \multirow[t]{2}{*}{0157} & F: CGGACATCCATGTGATATGG & \multirow[t]{2}{*}{$259 \mathrm{bp}$} & \multirow[t]{2}{*}{52} & \multirow{2}{*}{$\begin{array}{l}\text { (Mohamed } \\
\text { 2018) }\end{array}$} \\
\hline & & R: TTGCCTATGTACAGCTAATCC & & & \\
\hline \multirow{2}{*}{$\begin{array}{l}\text { Encoding } \mathrm{H7} \\
\text { flagellar antigens }\end{array}$} & \multirow[t]{2}{*}{$\mathrm{fliCH} 7$} & F: GCGCTGTCGAGTTCTATCGAGC & \multirow[t]{2}{*}{$625 \mathrm{bp}$} & \multirow[t]{2}{*}{60} & \multirow{2}{*}{$\begin{array}{l}\text { (Mohamed } \\
\text { 2018) }\end{array}$} \\
\hline & & $\begin{array}{l}\text { R: } \\
\text { CAACGGTGACTTTATCGCCATTCC }\end{array}$ & & & \\
\hline \multirow[t]{2}{*}{$\begin{array}{l}\text { Beta- } \\
\text { glucuronidase }\end{array}$} & \multirow[t]{2}{*}{ uidA } & $\begin{array}{l}\text { F: } \\
\text { ATCACCGTGGTGACGCATGTCGC }\end{array}$ & \multirow[t]{2}{*}{$486 \mathrm{bp}$} & \multirow[t]{2}{*}{56} & \multirow{2}{*}{$\begin{array}{l}\text { (Heininger } \\
\text { et al. } \\
1999 \text { ) }\end{array}$} \\
\hline & & $\begin{array}{l}\text { R: } \\
\text { CACCACGATGCCATGTTCATCTGC }\end{array}$ & & & \\
\hline
\end{tabular}

\section{Results}

In our study, $236 \mathrm{E}$. coli isolates were collected from the examination of 250 faecal samples of healthy cattle in Tunisia. Out of $236 \mathrm{E}$. coli isolates, 159 were from cattle in slaughterhouses and 77 from cattle from farms. Of these $E$. coli strains, $100 \%$ were positive for methyl-red, lactose and indol, and $100 \%$ were negative for urease, citrate and $\mathrm{H} 2 \mathrm{~S}$. The results revealed that $10 \mathrm{E}$. coli were nonfermenting of sorbitol on CT-SMAC and these 10 (4.2\%) strains were E. coli 0157:H7. Out the 10 strains; 6 isolates were isolated from healthly cattle in slaughterhouses and 4 from healthy cattle from farms.

All E. coli 0157:H7 isolates were susceptible to amoxicillin/clavulanic acid, cefotaxime, cefepime, aztreonam, colistin and sulfamethoxazole/trimethoprim. More than $80 \%$ of isolates were susceptible to ampicllin, cefoxitin, ticarcillin/clavulanic acid, ceftazidime, ertapenem, nalidixic acid, florfenicol, chloramphenicol and enrofloxacin. Howevere, resistance to cefuroxime, streptomycin and tetracycline was $50 \%, 40 \%$ and $30 \%$ respectively (Fig. 1).

The confirmation of E. coli 0157 by latex agglutination testing reveal that all isolates were 0157 positive. All of these isolates were confirmed as E. coli 0157:H7 via screening of $r f b 0157$ and flicH7 genes by specific primers.

PCR analysis of the 10 E. coli 0157 isolates reveals that $u i d A$, flicH7 and 0157 genes were present in all strains. Stx2 gene was present in 7 isolates (70\%), st 1 and $e h x A$ were confirmed in six isolates (60\%) whereas eae was identified in two isolates. 
We found four isolates carrying three virulence genes as follow; three strains harbored stx2, stx 1 and ehxA and one strain harbored stx2, eae and ehxA (Table 2). All E. coli 0157 isolates belong to the phylo-group $\mathrm{E}$.

The 0157 isolates were further tested for 13 virulence factors. All isolates carried at least one virulence gene tested. Out of 10 isolates, $60 \%$ carried more than three virulence gene tested. The fimH was the most frequent virulence gene and was detected in $90 \%(9 / 10)$ of the isolates, followed by $s f a / f o c D E 60 \%$. The frequency of cdt3, traT, and iutA among the isolates was 50\%, 50\%, and 40\% respectively, wherase, hly was the lowest virulence genes of $E$. coli isolates which was found in one isolates (Table 2). None of the isolates harbored $c n f 1$, aer, papA, bfpA, papG allele III, ibeA and fyuA.

Table 2

Distribution of virulence genes and specific genes detected by PCR

\begin{tabular}{|c|c|c|c|c|c|c|c|c|}
\hline \multirow[t]{2}{*}{ Bacterial code } & \multicolumn{3}{|c|}{ Specific genes } & \multicolumn{4}{|c|}{ STEC virulence markers } & \multirow[t]{2}{*}{ Virulence factors } \\
\hline & uidA & 0157 & fliCH7 & stx1 & stx2 & eae & ehxA & \\
\hline T46 & + & + & + & + & + & - & + & $c d t 3$, traT, fimH, sfa/focDE \\
\hline T48 & + & + & + & + & + & - & + & $c d t 3, s f a / f o c D E$ \\
\hline T51 & + & + & + & - & + & - & - & $c d t 3$, fimH, sfa/focDE, iutA \\
\hline T109 & + & + & + & - & + & - & + & $c d t 3$, fimH, sfa/focDE \\
\hline T125 & + & + & + & - & + & + & + & $h l y, c d t 3$, traT, fimH, sfa/focDE \\
\hline T132 & + & + & + & + & + & - & + & $\mathrm{fimH}$ \\
\hline BS10 & + & + & + & + & - & + & - & $\mathrm{fimH}$ \\
\hline BS37 & + & + & + & - & + & - & + & traT, sfa/focDE, fimH, iutA \\
\hline BS40 & + & + & + & + & - & - & - & traT, fimH, iutA \\
\hline BS43 & + & + & + & + & - & - & - & tra $T$, fim $H$, iutA \\
\hline
\end{tabular}

\section{Discussion}

Human infections caused by STEC 0157:H7 have particularly been distinguished to be originated from foods that come from animals. Particularly, cattle, sheep, and goats have been demonstraded as main natural reservoirs for STEC 0157:H7 and play an important role in the public health concern (Atnafie et al. 2017).

The high morbidity of this serotype around the world has been focused as a major public health threat. It can cause acute human infections and outbreaks. The STEC 0157 infection might involve abdominal pain, bloody diarrhea, hemorrhagic colitis (HC) and haemolytic uremic syndrome (HUS) (Zhang et al. 2006). The majority of E. coli 0157 infections in human are food borne and concerning with cattle sources.

A total of $236 \mathrm{E}$. coli isolates were collected from faecal samples of healthy cattle in Tunisia during a five-month time period in 2017 and nine months in 2018, and were evaluated for the incidence of E. coli 0157 and antimicrobial profiles. This is the first report concerning the presence of E. coli 0157:H7 in cattle in Tunisia. 
Our finding exhibited that among 236 E. coli isolates, ten E. coli 0157:H7 were detected with a rate of $4.2 \%$. These isolates were cultured on CT-SMAC agar as non-sorbitol fermenters and were confirmed as STEC 0157 by using latex agglutination and PCR. This is in agreement with other studies investigating E. coli 0157:H7 among cattle feces samples and carcass swabs in slaughterhouses where the prevalences were reported as $4.7 \%$ and $2.7 \%$ respectively in Ethiopia (Atnafie et al. 2017). In a study in United Arab Emirates, the prevalence of E. coli 0157:H7 among slaughtered cattle was 1.4\% (Al-Ajmi et al. 2020). An Algerian study reported an occurence of $E$. coli 0157 inmore than 7\% of bovine carcasses (Chahed et al. 2006). In Morocco, the incidence of E. coli 0157:H7 in dairy products and marketed meat products was $9.1 \%$ and $11.1 \%$ respectively (Benkerroum et al. 2004). In Tunisia, 327 E. colistrains were isolated from diarrheic and non-diarrheic people. By using PCR techniques it has been demonstraed that 11 isolates (3.4\%) express the stx gene encoding for STEC (EHEC) and only one (0.3\%) was confirmed as E. coli 0157:H7 (Al-Gallas et al. 2006).

In Africa, the highest incidence in cattle was 31.2\% representive in four studies. In Asian countries, the highest rates was $12.22 \%$ in Jordian cattle and the lowest $(0.13 \%)$ was evaluated in Taiwan. In Europe, the highest estimated occurrence was demonstrated from Italy (10.45\%) and the lowest from Norway (0.25\%). Furthermore, the USA incidence estimate was $7.60 \%$ among fourty studies (Islam et al. 2014).

Healthy cattle can be a main reservoir for prospect human infection, and it plays an important role in the epidemiology of STEC infections. Moreover, most human diseases by STEC bacteria orgininate from cattle (Mead, Griffin 1998). The existence of STEC 0157:H7 in our study among animal feces in slaughterhouses highlighted the possible contamination of meat products prepared for human consumption. On the other hand, identifying the STEC 0157:H7 in human is very important for public health objective, like finding outbreaks.

Antimicrobial resistance is considered as a global health threat. Food animals products have been demonstrated as reservoirs of antimicrobial resistant bacteria because the same genes encoded for antimicrobial resistance were demonstrated in the bacteria of animal food and in humans (Founou et al. 2016).

Our results show that all E. coli 0157:H7 isolates were susceptible to amoxicillin/clavulanic acid, cefotaxime, cefepime, aztreonam, colistin and sulfamethoxazole/trimethoprim. Previous studies in animals reported different antibiotics resistance profiles of E. coli 0157:H7 isolates. One study found that all E. coli 0157:H7 isolates were susceptible to cefotaxime, ceftriaxone, gentamycin, kanamycin and nalidixic acid (Atnafie et al. 2017). Further report showed that all isolates were susceptible to cefotaxime, chloramphenicol, ciprofloxacin, norfloxacin, and polymyxin B (Al-Ajmi et al. 2020). However, a Saudian study reported that the isolates were resistant to all used antibiotics (Al-Wabel 2007). One study in Iran revealed that resistance rate to gentamycin, ampicillin, erythromycin, amoxicillin and tetracycline was $56.0 \%, 48.0 \%, 40.0 \%, 16.0 \%$ and $12.0 \%$ respectively (Rahimi, Nayebpour 2012). A UK study in human showed that resistance profile among 327 STEC 0157 to ampicillin, streptomycin, trimethoprim/sulphonamide and tetracycline was $5.8 \%$ followed by the resistance rate in ciprofloxacin (2.6\%) and chloramphenicol (2.1\%) (Day et al. 2016).

A study conducted in Latin American countries has documented 78.5\% sensitivity to all the antimicrobial agents in 140157 STEC strains from cattle. Three strains were resistant to streptomycin, trimethoprim and sulfonamide (Bastos et al. 2006).

Antimicrobial resistance variation might be due to expression of resistance genes among bacteria in animals, environment or humans (Reuben, Owuna 2013). 
On the other hand, more than $40 \%$ of the isolates were resistant to cefuroxime and streptomycin, perhaps via inappropriate or wide use of drug for prophylactic purpose and treating infections.

In our study, most strains exihibed an intermediate resistance pattern, suggesting the possibility for future resistance. The intermediate susceptibility profiles should be elevated and take in consideration with resistance results because it means the organism may be at the way to resistant.

Shiga toxins (stx genotypes) are important factors of the clinical outcome which correlate with HC and HUS and the pathogenicity higher in the strains harbouring stX2 genotype (Kawano et al. 2008). The eae gene encoding for an intimin protein, which is important for attaching and effacing activity in host intestinal cells and cause severe human illnesses particularly HUS (Cornick et al. 2002). Furthermore, a hemolysin produced by STEC called enterohemolysin is encoded by $h l y A$ gene and cause erythrocyte lysis which participate in iron intake in the intestine. This gene is commonly used as epidemiological marker of STEC strains (Schwidder et al. 2019).

In this study, stx2 gene was present in most isolates, eae and ehxA were found in more than half of isolates. Many studies mentioned that virulence factors st 2 and eaeA are clinically significant and linked with the acuteness of human disease, particularly HUS (Friedrich et al. 2002,Beutin et al. 2004). In UAE, shiga toxin gene (stx2) were confirmed in all twenty four E. coli 0157 from camels, cattle and goats. The eaeA and $h / y A$ genes were present in $79.2 \%$ and $66.7 \%$ respectively,whereas stx 1 was absent in all isolates (Al-Ajmi et al. 2020).

An Ethiopian study revealed that prevalence of stx1, eae, hly and stx2 among 157 isolates E. coli were 11 (78.5\%), 6 (42.8\%), 3 (21.4\%) and 11 (78.5\%) respectively (Atnafie et al. 2017).

Our study showed that 9 STEC strains harbored fimH and half isolates harbored sfa/focDE, cdt3, traT, and iutA. These factors were identified in a previous study among E. coli from dairy farms in America (Pereira et al. 2011). In an Iraian study of STEC, they found papA, cnf1, traT and cnf2 the highest virulence genes (Momtaz et al. 2012). The detected factors contribute to virulence which affect of host cell processes and contribute to bacterial pathogenesis. The findings of these virulence factors in our isolates in associated with high prevalence of stx 1 , stx 2 and ehxA suggest that STEC 0157 in Tunisian calves may pose a serious public health concern.

The findings of our study revealed that all E. coli 0157 isolates belonged to phylogroup $\mathrm{E}$. This was identical to the report of Tenaillon et al. (Tenaillon et al. 2010). A study in Brazil demonstrated that $E$. coli belonging to phylogroups $E$ and $B 1$ were isolated from cattle, wherease phylogroups $A$ and $F$ were from poultry and B2 and D were associated with isolates from water buffalo (Morcatti Coura et al. 2015).

\section{Conclusions}

The prevalence of E. coli 0157:H7 in healthy cattle with some antibiotics resistance indicate a possibly risk to public health concern. The existence of STEC 0157:H7 in animal feces intended to slaughter highlighted the possible contamination of meat products prepared for human consumption. The high prevalence of stx 1 , stx 2 and ehxA with other virulence factors suggest that STEC 0157 in Tunisian calves may pose a serious public health concern. Our study reveals the necessity for a regular screening of E. coli 0157:H7 in animal in order to control this pathogen. It is important to take necessary measures in the slaughterhouse during the slaughter and skinning of animals to prevent cross contamination of meat by this pathogen. 


\section{Declarations}

Funding: This work was supported by the research project PEER 7-349 funded by the USAID "Monitoring of antimicrobial resistance of bacteria for a better health of animals in Tunisia". Prof. Lilia Messadi is the recipient of the funding (number PEER 7-349).

Conflicts of Conflicts of interest/Competing interests: The authors declare that they have no conflicts of interest.

Code availability: The datasets generated during and analysed during the current study are available in this manuscript.

Authors' Contributions: Ghassan Tayh designed the study, performed the experimental work (the microbiological and molecular tests), collected the data, analyzed and interpreted the data and drafted the manuscript. Salma Mariem Boubaker and Rym Ben Khedher collected samples and helped in performing the experimental part of the manuscript. Mounir Jbeli collected samples. Faten Ben Chehida, Aymen Mamlouk and Monia DâaloulJedidiparticipated in the project design. Lilia Messadi designed and supervised the study, and contributed to final writing and editing the manuscript. All authors read and approved the final version of the manuscript.

Ethics approval: Not applicable.

Consent to participate: All the authors consented to participate in this study. All authors read and approved the final manuscript.

Consent for publication: All the authors consent to publication of this article.

\section{References}

1. Tayh G, Sallem RB, Yahia HB, Gharsa H, Klibi N, Boudabous A, Slama KB (2016) First report of extendedspectrum $\beta$-lactamases among clinical isolates of Escherichia coli in Gaza Strip, Palestine. Journal of global antimicrobial resistance 6:17-21. doi:https://doi.org/10.1016/j.jgar.2016.01.013

2. Johnson JR, Russo TA (2002) Extraintestinal pathogenic Escherichia coli." the other bad E coli". J Lab Clin Med 139:155-162. doi:https://doi.org/10.1067/mlc.2002.121550

3. Hashish EA, El Damaty HM, Tartor YH, Abdelaal AM (2016) Epidemiological Study of Diarrheagenic Escherichia coli Virulence Genes in Newborn Calves. Pak Vet J 36.

4. Karmali MA (1989) Infection by verocytotoxin-producing Escherichia coli. Clin Microbiol Rev 2:15-38. doi:https://doi.org/10.1128/cmr.2.1.15

5. Persad AK, Lejeune JT (2015) Animal reservoirs of Shiga toxin-producing Escherichia coli. In: Enterohemorrhagic Escherichia coli and Other Shiga Toxin-Producing E. coli. American Society of Microbiology (ASM), pp 231-244. doi: https://doi.org/10.1128/9781555818791.ch11

6. Riley LW, Remis RS, Helgerson SD, McGee HB, Wells JG, Davis BR, Hebert RJ, Olcott ES, Johnson LM, Hargrett NT (1983) Hemorrhagic colitis associated with a rare Escherichia coli serotype. N Engl J Med 308:681-685. doi:https://doi.org/10.1056/NEJM198303243081203

7. Atnafie B, Paulos D, Abera M, Tefera G, Hailu D, Kasaye S, Amenu K (2017) Occurrence of Escherichia coli 0157: H7 in cattle feces and contamination of carcass and various contact surfaces in abattoir and butcher 
shops of Hawassa, Ethiopia. BMC Microbiol 17:24. doi:https://doi.org/10.1186/s12866-017-0938-1

8. García-Aljaro C, Muniesa M, Jofre J, Blanch AR (2004) Prevalence of the stx2 gene in coliform populations from aquatic environments. Appl Environ Microbiol 70:3535-3540.

doi:https://doi.org/10.1128/AEM.70.6.3535-3540.2004

9. Al-Gallas N, Bahri O, Aissa RB (2006) Prevalence of shiga toxin-producing Escherichia coli in a diarrheagenic Tunisian population, and the report of isolating STEC 0157: H7 in Tunis. Curr Microbiol 53:483-490. doi:https://doi.org/10.1007/s00284-006-0184-5

10. Chahed A, China B, Mainil J, Daube G (2006) Prevalence of enterohaemorrhagic Escherichia coli from serotype 0157 and other attaching and effacing Escherichia coli on bovine carcasses in Algeria. J Appl Microbiol 101:361-368. doi:https://doi.org/10.1111/j.1365-2672.2006.02954.x

11. Beneduce L, Spano G, Nabi AQ, Lamacchia F, Massa S, Aouni R, Hamama A (2008) Occurrence and characterization of Escherichia coli 0157 and other serotypes in raw meat products in Morocco. J Food Prot 71:2082-2086. doi:https://doi.org/10.4315/0362-028x-71.10.2082

12. Benkerroum N, Bouhlal Y, ATTAR AE, Marhaben A (2004) Occurrence of shiga toxin-producing Escherichia coli 0157 in selected dairy and meat products marketed in the city of Rabat, Morocco. J Food Prot 67:12341237. doi:https://doi.org/10.4315/0362-028x-67.6.1234.

13. Abdul-Raouf U, Ammar M, Beuchat L (1996) Isolation of Escherichia coli 0157: H7 from some Egyptian foods. Int J Food Microbiol 29:423-426. doi:https://doi.org/10.1016/0168-1605(95)00076-3

14. Lupindu AM (2018) Epidemiology of Shiga toxin-producing Escherichia coli 0157: H7 in Africa in review. S Afr J Infect Dis 33:24-30. doi:https://doi.org/10.1080/23120053.2017.1376558

15. Gannon V, D'souza S, Graham T, King R, Rahn K, Read S (1997) Use of the flagellar H7 gene as a target in multiplex PCR assays and improved specificity in identification of enterohemorrhagic Escherichia coli strains. J Clin Microbiol 35:656-662. doi:https://doi.org/10.1128/JCM.35.3.656-662.1997

16. Al-Ajmi D, Rahman S, Banu S (2020) Occurrence, virulence genes, and antimicrobial profiles of Escherichia coli 0157 isolated from ruminants slaughtered in Al Ain, United Arab Emirates. BMC Microbiol 20:1-10. doi:https://doi.org/10.1186/s12866-020-01899-0

17. Clermont O, Christenson JK, Denamur E, Gordon DM (2013) The Clermont Escherichia coli phylo-typing method revisited: improvement of specificity and detection of new phylo-groups. Environ Microbiol Rep 5:5865. doi:https://doi.org/10.1111/1758-2229.12019

18. Sjöling Å, Sadeghipoorjahromi L, Novak D, Tobias J (2015) Detection of major diarrheagenic bacterial pathogens by multiplex PCR panels. Microbiol Res 172:34-40.

doi:https://doi.org/10.1016/j.micres.2014.12.003

19. Grispoldi L, Bertero F, Franceschini S, Mastrosimone F, Sechi P, lulietto MF, Ceccarelli M, Cenci-Goga BT (2017) Prevalence and characterisation of shigatoxigenic Escherichia coli isolated from beef cattle fed with prebiotics. Ital J Food Saf 6. doi:https://doi.org/10.4081/ijfs.2017.6958

20. Ranjbar R, Masoudimanesh M, Dehkordi FS, Jonaidi-Jafari N, Rahimi E (2017) Shiga (Vero)-toxin producing Escherichia coli isolated from the hospital foods; virulence factors, o-serogroups and antimicrobial resistance properties. Antimicrob Resist Infect Control 6:4. doi:https://doi.org/10.1186/s13756-016-0163-y

21. Mohamed HS (2018) Detection of Virulence Factors of Escherichia coli Strains Isolated from Children with Diarrhea. EC Microbiology (ECMI) 14:475-486.

Page $12 / 14$ 
22. Heininger A, Binder M, Schmidt S, Unertl K, Botzenhart K, Döring G (1999) PCR and blood culture for detection of Escherichia coli bacteremia in rats. J Clin Microbiol 37:2479-2482.

doi:https://doi.org/10.1128/JCM.37.8.2479-2482.1999.

23. Zhang W, Qi W, Albert TJ, Motiwala AS, Alland D, Hyytia-Trees EK, Ribot EM, Fields PI, Whittam TS, Swaminathan B (2006) Probing genomic diversity and evolution of Escherichia coli 0157 by single nucleotide polymorphisms. Genome Res 16:757-767. doi:https://doi.org/10.1101/gr.4759706

24. Islam MZ, Musekiwa A, Islam K, Ahmed S, Chowdhury S, Ahad A, Biswas PK (2014) Regional variation in the prevalence of E. coli 0157 in cattle: a meta-analysis and meta-regression. PLoS One 9:e93299. doi:https://doi.org/10.1371/journal.pone.0093299

25. Mead PS, Griffin PM (1998) Escherichia coli 0157: H7. The Lancet 352:1207-1212. doi:https://doi.org/10.1016/S0140-6736(98)01267-7

26. Founou LL, Founou RC, Essack SY (2016) Antibiotic resistance in the food chain: a developing countryperspective. Front Microbiol 7:1881. doi:https://doi.org/10.3389/fmicb.2016.01881

27. AI-Wabel NA (2007) ANTIBIOTIC SUSCEPTIBILITY OF E. COLI 0157: H7 ISOLATED FROM BEEFBURGER. B PHARM SCI 30:131-134. doi:https://doi.org/10.21608/BFSA.2007.64179

28. Rahimi E, Nayebpour F (2012) Antimicrobial resistance of Escherichia coli O 157: H7/NM isolated from feaces of ruminant animals in Iran. J Cell Anim Biol 6:104-108. doi:https://doi.org/10.5897/JCAB11.082

29. Day M, Doumith M, Jenkins C, Dallman TJ, Hopkins KL, Elson R, Godbole G, Woodford N (2016) Antimicrobial resistance in Shiga toxin-producing Escherichia coli serogroups 0157 and 026 isolated from human cases of diarrhoeal disease in England, 2015. J Antimicrob Chemother 72:145-152. doi:https://doi.org/10.1093/jac/dkw371

30. Bastos FC, Vaz TMI, Irino K, Guth BEC (2006) Phenotypic characteristics, virulence profile and genetic relatedness of 0157 Shiga toxin-producing Escherichia coli isolated in Brazil and other Latin American countries. FEMS Microbiol Lett 265:89-97. doi:https://doi.org/10.1111/j.1574-6968.2006.00472.x

31. Reuben R, Owuna G (2013) Antimicrobial resistance patterns of Escherichia coli 0157: H7 from Nigerian fermented milk samples in Nasarawa State, Nigeria. Int J Pharm Sci Invent 2:38-44.

32. Kawano K, Okada M, Haga T, Maeda K, Goto Y (2008) Relationship between pathogenicity for humans and stx genotype in Shiga toxin-producing Escherichia coli serotype 0157. Eur J Clin Microbiol Infect Dis 27:227232. doi:https://doi.org/10.1007/s10096-007-0420-3

33. Cornick NA, Booher SL, Moon HW (2002) Intimin facilitates colonization by Escherichia coli 0157 : H7 in adult ruminants. Infect Immun 70:2704-2707. doi:https://doi.org/10.1128/iai.70.5.2704-2707.2002

34. Schwidder M, Heinisch L, Schmidt H (2019) Genetics, toxicity, and distribution of enterohemorrhagic Escherichia coli hemolysin. Toxins 11:502. doi:https://doi.org/10.3390/toxins11090502

35. Friedrich AW, Bielaszewska M, Zhang W-L, Pulz M, Kuczius T, Ammon A, Karch H (2002) Escherichia coli harboring Shiga toxin 2 gene variants: frequency and association with clinical symptoms. J Infect Dis 185:74-84. doi:https://doi.org/10.1086/338115

36. Beutin L, Krause G, Zimmermann S, Kaulfuss S, Gleier K (2004) Characterization of Shiga toxin-producing Escherichia coli strains isolated from human patients in Germany over a 3-year period. J Clin Microbiol 42:1099-1108. doi:https://doi.org/10.1128/JCM.42.3.1099-1108.2004. 
37. Pereira RVV, Santos T, Bicalho M, Caixeta L, Machado V, Bicalho R (2011) Antimicrobial resistance and prevalence of virulence factor genes in fecal Escherichia coli of Holstein calves fed milk with and without antimicrobials. Int J Dairy Sci 94:4556-4565. doi:https://doi.org/10.3168/jds.2011-4337

38. Momtaz H, Farzan R, Rahimi E, Safarpoor Dehkordi F, Souod N (2012) Molecular characterization of Shiga toxin-producing Escherichia coli isolated from ruminant and donkey raw milk samples and traditional dairy products in Iran. Sci World J 2012. doi:https://doi.org/10.1100/2012/231342

39. Tenaillon O, Skurnik D, Picard B, Denamur E (2010) The population genetics of commensal Escherichia coli. Nat Rev Microbiol 8:207-217. doi:https://doi.org/10.1100/2012/231342.

40. Morcatti Coura F, Diniz SdA, Silva MX, Mussi JMS, Barbosa SM, Lage AP, Heinemann MB (2015)

Phylogenetic group determination of Escherichia coli isolated from animals samples. Sci World J 2015. doi:https://doi.org/10.1155/2015/258424

\section{Figures}

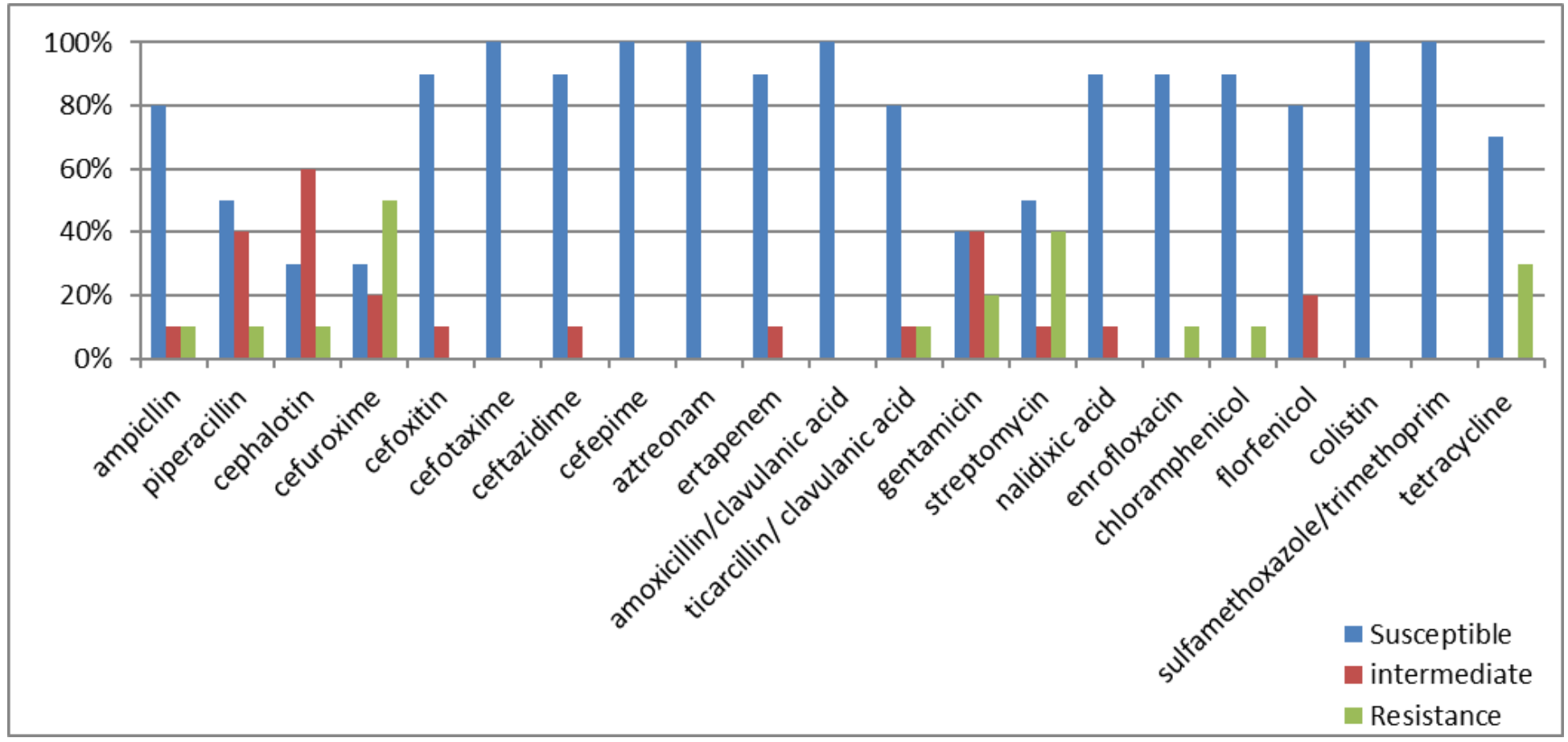

\section{Figure 1}

Antimicrobial susceptibility of E. coli 0157:H7 isolates. 